\title{
Non-formal education for schistosomiasis prevention: the experience of the Museu Arqueológico de Central, Bahia, Brazil
}

\author{
Andreia Alves Soares/ ${ }^{+}$, Silvana Carvalho Thiengo, Marilene de Sá Cadei*, \\ Martha Locks**, Maria Beltrão**, Monica Ammon Fernandez
}

\author{
Departamento de Malacologia, Instituto Oswaldo Cruz-Fiocruz, Av. Brasil 4365, 21040-900 Rio de Janeiro, RJ, Brasil \\ *Departamento de Ensino de Ciências e Biologia, Uerj, Rio de Janeiro, RJ, Brasil **Departamento de Antropologia, \\ Setor de Arqueologia, Museu Nacional, UFRJ, Rio de Janeiro, RJ, Brasil
}

\begin{abstract}
The activities described here form part of an extensive programme in place in the Região Arqueológica de Central, state of Bahia, Brazil. After malacological and socio-environmental surveys in the area, a strategy comprising formal and non-formal education with an emphasis on schistosomiasis prevention was developed, introduced, and evaluated. Interviews were conducted of 142 students and 11 teachers, totalling 11 classes at six primary schools. On the basis of those interviews, four display cases and seven panels were prepared. In addition a table was set up where students could participate directly on the subject, drawing and recognising the factors involved in the schistosomiasis cycle. The exhibition was held at the Museu Arqueológico de Central. The endeavours of this paper underline the importance of health education as well as exhibitions to disease prevention activities.
\end{abstract}

Key words: schistosomiasis mansoni - health education - freshwater snails - Bahia - Brazil

These activities form part of a larger study, "Projeto Central" conducted by a team from the Archaeology Sector of the Anthropology Department, Museu Nacional, Rio de Janeiro Federal University. The Região Arqueológica de Central, in the state of Bahia, currently covers an area of $100,000 \mathrm{~km}^{2}$ and "Projeto Central" is housed in the municipality of Central $\left(11^{\circ} 08^{\prime} \mathrm{S} 42^{\circ} 07^{\prime} \mathrm{W}\right.$ ) (Beltrão et al. 2003).

Samples of sub-recent and recent freshwater snail shells were gathered in this area in field activities between 1997 and 2002. This material was studied by Soares (2004), who identified four species: Asolene meta (Ihering, 1915), Biomphalaria aff. glabrata (Say, 1818), Biomphalaria straminea (Dunker, 1848), and Pomacea lineata (Spix, 1827).

Bahia comprises areas with high, medium, and low endemicity of schistosomiasis mansoni and ranks 4th among Brazilian states in number of hospital admissions due to this endemic disease (Passos \& Amaral 1998). Added to the fact that sub-recent schistosomiasis vector snails were found in the Região Arqueológica de Central, a malacological survey was performed in current biotopes present in the area during May and July 2004 and January 2005. This survey, which formed part of the lead author's Masters thesis, yielded eight species, among them B. straminea, an intermediate host of Schistosoma mansoni Sambon, 1907. Data concerning the malacological survey will be published elsewhere.

Financial support: Finep, CNPq, Governo do Estado da Bahia ${ }^{+}$Corresponding author. andreiapaleobio@yahoo.com.br Received 25 May 2006

Accepted 26 June 2006
Although there has been no notification of schistosomiasis in the municipality of Central, important factors such as the presence of intermediate hosts, precarious sanitation, a population whose leisure, and domestic activities include close contact with waterbodies and the proximity of municipalities with areas of low transmission - leave this region vulnerable to the emergence of schistosomiasis foci, and thus call for preventive measures.

Diniz (2003) points out that it is not enough to learn about the phenomena that cause a disease or memorise scientific names and transmission cycles. For knowledge to be constructed in such a way, it must stem from internal motivations and take account of the context where they are encountered.

In that light it was proposed to develop a non-formal strategy to circulate knowledge on malacology and schistosomiasis prevention tailored to local socio-environmental conditions. A range of activities, such as talks or working with health agents, could be recommended to raise awareness on the subjects in question, but the most appropriate was to set up an educational exhibition at the Museu Arqueológico de Central (MAC), which already constitutes an important setting for non-formal education. Education in museums offers a variety of forms of communication, providing information on cultural heritage, the relationship of dialogue between educator and those being educated, and can arouse curiosity and great pleasure among its visiting public, in addition to seeking to build citizenship (Studart 2004).

MAC was chosen to house the exhibition because it had been used successfully as a vehicle for socialising scientific knowledge by the team of "Projeto Central", which is designed to raise awareness of archaeology in the localities studied. In addition, MAC is located near a weekly local market, facilitating visits by people from outlying villages who only travel to town on Saturdays (Locks et al. 2005). Set up in 1995, MAC serves as a laboratory where the impacts caused by modifications to the exhibi- 
tions are measured annually, in order to evaluate its capacity to spread scientific information.

As the strategy proposed in this study is tailored to the target population's social and environmental realities, information had to be gathered on local conditions. The methodology used combined quantitative research (the social and environmental survey) with qualitative research (the case study).

In order to socio-environmentally characterize the region, structured interviews of students and teachers were conducted with a view to determining local knowledge of schistosomiasis and basic sanitation conditions. Six schools in the area took part in the study, two of them in the town of Central and four in nearby villages (Veredas de Central, São João de Zé de Preta, and Roçadinho), corresponding to 11 primary school classes. The interviews, held at the schools, were individual and lasted on average $20 \mathrm{~min}$.

The educational exhibition was developed on the basis of existing information on the local malacofauna combined with what was obtained during the interviews, the teachers' and students' knowledge of schistosomiasis and local sanitation conditions.

The information was organized after a process that progressed from didactic transposition to re-contextualization (Marandino 2002) and was distributed according to the following thematic areas: 1 - general features of molluscs; 2 - types of molluscs; 3 - relationship of molluses to man; 4 - distribution of species in the Archaeological Region of Central; 5 - what is schistosomiasis; 6 - schistosomiasis cycle; and 7 - schistosomiasis in Brazil.

The social and environmental profile was surveyed in May 2004 by way of structured interviews of 142 students and 11 teachers randomly chosen. The intention was not to make a detailed analysis of the obtained data, but rather to use them as support in developing the educational exhibition. Three out of six questions explored the students' knowledge and three the teachers'.

When the students were asked questions on the subject of schistosomiasis, $21.1 \%$ of the interviewees had noted the presence of the snail in the area, $4.2 \%$ reported knowing what schistosomiasis was, $2.1 \%$ remembered hearing about the subject at school, and none knew of occurrences of the disease in their family. The same questions made to the teachers revealed that $72.7 \%$ had noted the snail in the area, $54.5 \%$ knew about schistosomiasis, $9 \%$ talked about the subject during class, and none knew of cases of schistosomiasis among their students. Comparing the data gathered from both groups, large percentage differences can be seen in their knowledge. Therefore, it may be inferred that the teachers' knowledge was not being used in effective teaching activities. This is confirmed by the fact that only one of the teachers reported addressing the subject in school.

Questions to the students on their knowledge of water supply and organic waste disposal revealed that $64 \%$ lived where water supply is maintained by the government, however there is no sewer system, and waste water drains into cesspits $(69 \%)$ or is discharged into ditches $(18.3 \%)$. Of the respondents, $12.6 \%$ had no toilet, "the bushes" being cited as the place for defecation. As regards the quantity and quality of the water supply, $37.3 \%$ reported occasions when supply to their homes had been interrupted and $86.6 \%$ mentioned procedures where the water supplied was filtered, boiled or strained.

Regarding water supplies, $35.9 \%$ of the students reported that water came to their homes from tanks, cisterns, wells, and streams. This, added to the occasional interruptions of water supplies and the absence of a sewer network, places the whole population at risk as they use water that is not always proper for consumption. The lack of a general sewer system may possibly be justified by the lack of rivers to serve as sinks for the waste. As the eggs of S. mansoni are eliminated with faeces, the lack of appropriate sanitary installations poses the risk of transmission of the parasite.

When the teachers were asked whether or not they addressed the subject of "Health Education", $54.5 \%$ reported that they acknowledge it in their classroom activities, $27.2 \%$ do not deal with it, and $18.1 \%$ refer to it both in school and in the community. They explained that, when it is addressed, this generally occurs at science or health fairs. Asked what the area's major health problems were, the teachers pointed to influenza as the most important (31.5\%), followed by skin conditions (21\%), helminthosis $(10.5 \%)$, dysentery $(5.2 \%)$, malnutrition $(5.2 \%)$, cholera (5.2\%), jigger fleas (5.2\%), Hansen's disease (5.2\%), hepatitis $(5.2 \%)$, and meningitis (5.2\%).

Although most of the teachers reported knowing what schistosomiasis is, this parasitic disease was not mentioned as a health problem, nor was it singled out as one of the subjects addressed at school. One of the possible reasons for this is that the disease is not seen as a local problem. Another possibility is that there is little depth to the teachers' knowledge: they can name the disease without, however, being able to describe the symptoms or transmission cycle.

The educational exhibition was prepared in the form of seven panels and four display cases arranged according to the seven thematic directions and disposed so as to offer visitors a sequence by which they could construct their knowledge of the theme, without however preventing them from following a route of their own. The panels contained figures and information designed to encourage visitors to increase their knowledge on the subject and also to relate it to their daily lives. Photographs and information obtained in the Archaeological Region of Central were included for that purpose.

The material shown in the display cases was distributed into two groups: one containing shells and the other, representations of a local environment. The shells were arranged in two display cases, the first containing specimens of several species and the second, only snails found in the area.

The representation of the local environment was organized in the form of models in two display cases showing the local people's daily activities. The first (Fig. 1) portrayed where schistosomiasis is transmitted, such as people washing clothes and children bathing in a pond which could be contaminated, faeces scattered near the pond. The other model showed preventive action, such as basic sanitation and education (Fig. 2). 


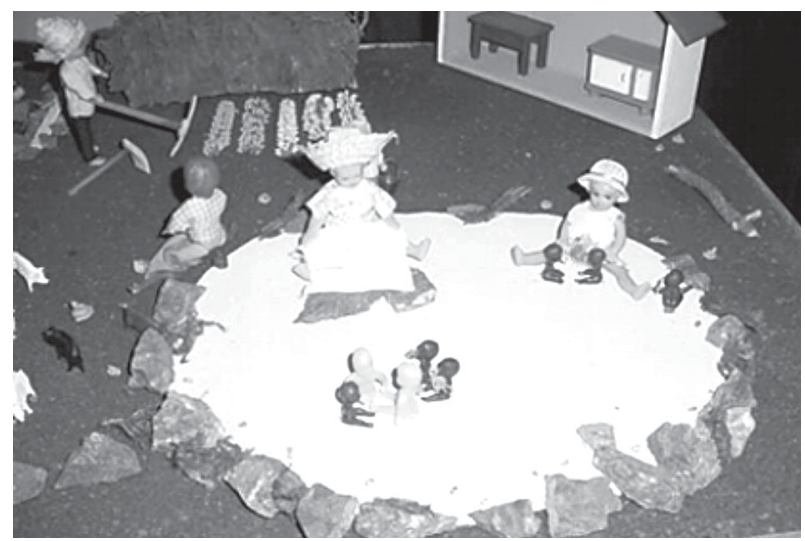

Fig. 1: models in display case showing available situations for schistosomiasis transmission.

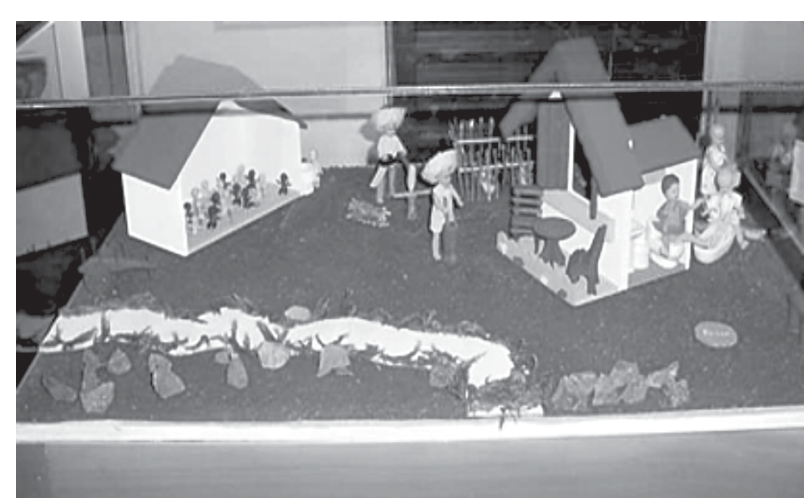

Fig. 2: models in display case illustrating preventive actions against schistosomiasis transmission.

To complement the exhibition, a table was set up with play activities, where visitors could consolidate their knowledge still further by drawing snails on a plastic sheet, looking for the schistosomiasis vector snail in the material provided and identifying the environments where schistosomiasis transmission could occur.

The data on the class visits during the exhibition call for complementary analyses that are now being carried out. Nonetheless, this paper demonstrates that partnering between museum and school makes it possible to integrate formal and non-formal teaching activities, thus contributing not just to promote culture in the region, but also to public health.

Many challenges have to be met for the relationship between formal and non-formal education to be based on work that respects the specific features of both domains. Without a doubt, however, partnering is believed to be the key to working in that direction. What is argued here is that a museum, building on its own particular strengths and integrating its efforts with schools, can develop an educational function of its own and make a distinct contribution to scientific knowledege literacy among the general public.

Although no cases of schistosomiasis have been notified in the area, factors relating directly to transmission make it possible for such an endemic to develop. Prophylaxis, including obviously health education measures, is thus of unquestionable relevance. In addition, schistosomiasis does not result solely from the presence of infected snails and diseased individuals, but also from the habits, customs, and traditions of the local population (Schall et al. 1987).

There is a need to improve the life quality of this population, by mobilising the community so as to change attitudes and practices that can favour and perpetuate transmission. According to Massara and Schall (2004), teachers and students are active agents for introducing new ideas into the community, because they are its permanent members.

By means of an educational program directed to local socio-environmental realities and by integrating formal and non-formal education, this project aimed to act towards preventing schistosomiasis in what is a vulnerable area, the municipality of Central, and to contribute to promoting the health of its population.

Due to Brazilian territory vast size and its diversity in terms of customs and environmental, social, and economic conditions, similar studies should be carried on aiming to improve population's life quality.

\section{ACKNOWLEDGEMENTS}

To Carlos Alberto de Oliveira, Paulo Batista de Oliveira, and Paracelso Honorato de Souza for their invaluable collaboration during the field work.

\section{REFERENCES}

Beltrão M, Locks M, Amorim J 2003. 20 Anos de Projeto Central, Estado da Bahia, Brasil. Annals of XII Congresso da Sociedade de Arqueologia Brasileira, São Paulo, 69 pp.

Diniz MCP 2003. As Representações Sociais da Esquistossomose de Escolares de Área Endêmica de Minas Gerais, MSc Thesis, Faculdade de Educação, UFMG, Belo Horizonte, $106 \mathrm{pp}$.

Locks M, Beltrão M, Soares AA 2005. Museu Arqueológico de Central: um exemplo de divulgação científica no interior da Bahia, Brasil. $9^{a}$ Reunión de la Red de Popularización de la Ciencia y la Tecnología para América Latina y el Caribe, Abril 9, Rio de Janeiro, Brasil.

Marandino M 2002. Da transposição a recontextualização: sobre a transformação do discurso científico na elaboração de exposições de museus. Annals of $25^{\mathrm{a}}$ Reunião Anual da Associação Nacional de Pós-Graduação e Pesquisa em Educação, Caxambu.

Massara CL, Schall VT 2004. A pedagogical approach of schistosomiasis - An experience in health educacion in Minas Gerais, Brazil. Mem Inst Oswaldo Cruz 99 (Suppl. I):113119.

Passos ADC, Amaral RS 1998. Esquistossomose mansônica: aspectos epidemiológicos e de controle. Rev Soc Bras Med Trop 31 (Supl. II): 61-74.

Schall VT Jurberg P, Almeida EM, Casz C, Cavalcante F, Bagno S 1987. Educação sanitária para alunos de primeiro grau: avaliação de um material de ensino e profilaxia da esquistossomose. Rev Saúde Públ 21: 387-404. 
Studart DC 2004. Educação em museus: produto ou processo? Dossiê CECA-Brasil. Musas Rev Bras Museus e Museologia 1: 34-40.

Soares AA 2004. Gastrópodes Límnicos Sub-recentes e Recentes da Região Arqueológica de Central, Bahia, Curso de Especialização em Malacologia de Vetores, Instituto Oswaldo Cruz-Fiocruz, Rio de Janeiro. Monografia: $27 \mathrm{pp}$. 